\title{
The formation of the West German power metal scene and the question of a 'Teu- tonic' sound
}

\author{
Jan-Peter Herbst
}

\begin{abstract}
Despite being one of the oldest and largest metal nations, little research on metal music from Germany exists. The current article focuses on the formation of the West German power metal scene. This subgenre was one of the first to be played in Germany, and bands such as Helloween, Running Wild, Gamma Ray and Blind Guardian produced a characteristic German sound that was to become famous in the world. Based on interviews with music producers, musicians, journalists and academics, this study analyses stylistic musical features of (German) power metal, the artists' influences and their different aspirations for international success. The findings suggest that a characteristic German power metal sound emerged in the 1980s and '90s that might be called 'Teutonic'. Germany was amongst the first countries to burst out countless successful power metal bands before the genre spread to other parts of the world. No standards existed in those days, and production resources were limited and individual. This restricted infrastructure - the unique characteristics of a few recording studios along with the small circle of professional musicians, engineers and producers - has shaped the classic German power metal sound. With standardisation of production resources, new techniques and consequences of globalisation such as internationally operating record labels, American culture in public media and increased English language skills, these national characteristics gradually diminished.
\end{abstract}

\section{Introduction}

From its beginning, the multidisciplinary field now called metal music studies has been interested in reconstructing the genre's history from its emergence in the United Kingdom and the United States of America around the 1970s, its spread across Continental Europe, Australia and Japan in the 1980s, and its expansion throughout the world since the 1990s (Wallach, Berger \& Greene 2011: 5). Whilst early work focused on the genre's emergence and thus on the UK and US (Weinstein 1991), the discipline has seen a rising interest in metal music cultures outside the Global North (Wallach, Berger \& Greene 2011; Brown, Spracklen, Kahn-Harris \& Scott 2016). Many journalistic metal histories (Christe 2004; Wiederhorn \& Turman 2014) have supported the special status of the UK and US, important genres and key artists described in early academic work, but likewise have overlooked relevant artists from European countries and certain genres. It is striking that power metal as one of the oldest metal genres, having emerged over 30 years ago, has not yet been paid considerable attention to in metal research. Moreover, metal from Germany, one of the largest metal communities in the world, has been acknowledged in metal historiography very rarely. If it did so, then either in the context of thrash metal with bands like Kreator, Sodom and Destruction (Kahn-Harris 2007: 116; Wiederhorn \& Turman 2013: 254; Christe 2004: 138), or it was Rammstein being discussed as the prototypical German rock band (Burns 2008; Kahnke 2013). German power metal, notwithstanding its huge success and longstanding popularity in Europe, America and Asia, is just mentioned in passing at best (Weinstein 1991: 118; Kahn-Harris 2007: 116; Sharpe-Young 2003: i). It appears that researchers outside of Germany have taken little interest in German metal, and neither did German scholars care much. One of the rare sources available is the already dated German-language journalistic book Heavy Metal - Made in Germany (1998) by Mader, Otger, Jeske and Hofmann. Their announced second volume, however, has never been published. ${ }^{1}$ Only recently,

\footnotetext{
${ }^{1}$ In recent years several journalistic books on German metal have been released, covering major metal regions like the Ruhr Area (Schmenk \& Krumm 2010: Schmenk \& Schiffmann 2017), the thrash metal bands Kreator (Bender
} 
Elflein (2017) explored the emergence of heavy metal in West Germany based on an empirical reconstruction of the scene by analysing early metal magazines, record labels and bands. $\mathrm{He}$ concluded his investigation by describing the need to analyse "the specific appropriation of Anglo-Saxon musical styles by German musicians and their further development into regionally defined styles like teutonic metal" (Elflein 2017: 122), naming Accept and Helloween as examples of renowned "Teutonic power bands".

This research project builds on Elflein's initial work and explores the development of German power metal' in the $1980 \mathrm{~s}$ and ' $90 \mathrm{~s}$. After briefly discussing the connotations of the 'Teutonic' label, it will explore whether there is, or has ever been, such a thing as a 'Teutonic' metal sound, as labelled by Elflein. Insights into music production resources, recording practices and stylistic features will complement Elflein's findings from practitioners' perspectives. Due to the lack of academic literature, the study follows an interview design with German metal producers, musicians and journalists plus international metal experts.

\section{The 'Teutonic' label}

For a long time, music media have been using the label 'Teutonic', which first was attributed from abroad by the British media. When English radio DJ John Peel introduced 'Krautrock' to describe a German form of psychedelic rock in the late 1960s and early '70s, the British music press took on this term and used it interchangeably with 'Teutonic Rock' (Adelt 2012: 361). Soon pioneer bands of German popular music like Kraftwerk adapted this expression and transformed national stereotypes into musical characteristics, "We have a Teutonic rhythm, really Germanic" as Ralf Hütter once claimed (Barr 1998: 142). In their work and presentation, Kraftwerk "drew on European classical music, emphasized melody, and used German lyrics and German accents to create a semiironic Teutonic identity that played with stereotypes of Germans as robotic automatons" (Adelt 2012: 372). This image, created by the foreign press and performed by Kraftwerk, was eventually adapted by German media that illustrated Kraftwerk as a "Teutonic machine [...] detached and motorized" (Rüther 2009) and as a "typically German band abroad: distanced, cold, perfectionist and highly effective" (Dallach 2003: 154).

In the metal press, it again was the British media first using the 'Teutonic' label to describe every metal band from Germany, irrespective of their style or sound, in continuation of past 'Krautrock' as demonstrated by a Kerrang! review of Rammstein's debut Herzeleid (1995): "Worryingly stern-faced industrial noise that is so Teutonic it wouldn't come as a surprise if it actually turned out to be a spoof by a bunch of Monty Python-esque satirists. For krautophiles and comedy fans only" (Kerrang! 1996: 45). The term was already common in the 1980s, characterising Accept as "Teutonic titans" (Kerrang! 1986: 6) and their sound as "Teutonic mayhem" (Reynolds 1989: 25), or picturing Helloween as a "bunch of Teutonic sub-Thrash martinets" (Dome 1987: 16). Often the 'Teutonic' label was nothing more than a meaningless journalistic phrase, but sometimes it matched the musical and cultural stereotypes in the tradition of Kraftwerk as demonstrated in a Rammstein concert review: "classically Teutonic; all metronomic rhythms, guttural vocals and, in the case of 'Links $2,3,4$ ' [...] the sound of a thousand marching footsteps. Predictable, certainly, but as devastatingly effective as a Volkswagen up the arsch [ass]" (Everley 2001: 44). The martial connotations were extended by regular side notes like "don't mention the war" in interview style articles, demonstrating the still present slight uneasiness of British journalists with German bands in the 1980s, enhanced through the

2011) and Tankard (Schuhmacher 2014) as well as the important record label Noise (Gehlke 2017). All these sources, except for Gehlke (2017), are only available in German.

${ }^{2}$ Following Elflein's (2017: 116) argumentation, bands from East Germany will not be taken into account as none of them had significant international success after the German reunification. For research on the metal scene formation in 1980s East Germany see Okunew 2016 and Zaddach 2016. 
communication barrier as a result of lacking command of the English language by most German musicians.

Such dubious connotations made the German metal press hesitant to use the term 'Teutonic'. In December 1985 the German Metal Hammer started a column named 'German Metal Attack' that in June 1987 was renamed to 'New Wave of German Heavy Metal'. It was not before 1992 that the adjective 'Teutonic' regularly came to depict the typically German style of heavy metal from bands such as Running Wild (Schöwe 1992a) or Grave Digger (Schöwe 1992b), this however might only reflect the writing style of individual journalists employed in those times. The magazine Rock Hard widely ignored the term 'Teutonic' even though they released the samplers Teutonic Invasion part I (1987) and part II (1988) in collaboration with Holland-based Roadrunner label. When Accept, Grave Digger, Running Wild and Helloween had their first international successes, the German media initiated the term 'First Wave of German Heavy Metal' but eventually shortened it to 'German Metal' or 'Teutonic Metal' (Schöwe 2002). For example, the Rock Hard claimed it was Accept having originated 'Teutonic power metal' (Stappert 2004: 92). Ever since, the 'Teutonic' label has commonly been used to either describe the characteristic form of German thrash metal by the so-called 'Teutonic Four' Kreator, Sodom, Destruction and Tankard - or it refers to classic heavy metal in the tradition of Accept. Especially the latter characterises 'Teutonic' as a rather simple form of metal, often interpreted as something typically German, not uncommonly in a mocking or even condescending manner (Duden 2018). On the other hand, it may refer to the ancient warrior tribes of the Teutons - a term also invented by foreign writers, the Romans describing the Furor Teutonicus (Teutonic Fury) ${ }^{3}$-, stressing the martial associations similar to the label 'Viking metal' and thus to characterise the power of the music or other cultural connotations.

Attempting to define the musical sound of a culture or nation proves problematic. First of all, the geographical boundaries have to be questioned. The Metal Hammer article (Schurer 2009) outlines the 'Teutonic' region as Germany, Austria and Switzerland, which historically is not true since the Teuton tribes resided in the north of Germany and Scandinavia and lived long before national states existed (approx. $4^{\text {th }}$ century BC). Even the equation of Germanic tribes and Germany is disputed (Heesch 2014). ${ }^{4}$ Rather, German music must be understood as a form of culture produced in an imagined community (Anderson 1990) within symbolic boundaries (Cohen 1985). As such, labels like 'Teutonic' characterise "some kind of averaged viewpoint, a collection of stereotypes and myths" (Spracklen \& Henderson 2013: 236) from the past, helping the metal press describe the cultural practices of bands at a time when metal music started to emerge globally (Weinstein 1991; Wallach, Berger \& Greene 2011: 5). Whether or not the labels 'Teutonic' or 'Viking' bear a musical meaning has not yet been explored in metal music studies. Doing so would require analysing musical aspects such as composition, arrangement, instrumentation, performance, recording and production, let alone further aspects beyond the music itself. This project aims to make a start on such an investigation, concentrating on music production resources, recording practices and stylistic features of the first generation of German power metal.

\section{Interview sample}

The sampling was purposive to gain complementary views from different areas of expertise and national backgrounds. In-depth interviews structured by a schedule were all conducted in German between 19 June 2017 and 10 March 2018 and then translated into English. They lasted

\footnotetext{
${ }^{3}$ It can also refer to the 'Teutonic Order' of the Middle Ages with associations to Teutonic Knights.

${ }^{4}$ Germanic mythology is commonly mingled with Nordic mythology as from 1796 when German philosopher Johann Gottfried Herder called to adapt it for the lack of a Germanic one. The Grimm Brothers' successful works strengthened this analogy. However, the continuity of Nordic-Germanic-German is historically and culturally disputed (Heesch 2014).
} 
between 27 and 123 minutes with an average length of 55 minutes. All participants consented to their name being disclosed.

Four of the seven interviewees were internationally active metal producers. The most experienced respondent within the area of study was Karl Rudolf 'Charlie' Bauerfeind (54 years) who produced the German power metal bands Helloween, Gamma Ray, Running Wild, Michael Kiske, Blind Guardian, Rage, Brainstorm, Freedom Call, Sieges Even and Axel Rudi Pell next to non-German bands like Angra, Viper, HammerFall, Saxon, Motörhead, Rob Halford and Venom. Siegfried 'Siggi' Bemm (61 years) was one of the main producers for the early Century Media label, having worked with Kreator, Rotting Christ, Sentenced, Morgoth, Samael, Tiamat, Angel Dust, Lacuna Coil and The Gathering. Lasse Lammert (36 years) produced Gloryhammer, Alestorm, MessengeR, Svartsot, Inner Sanctum, Primitai, Rumahoy and The Atlas Moth. In addition to the three German producers, one British perspective was provided by Mark Mynett (48 years), producer of Rotting Christ, Godsized and Paradise Lost and senior lecturer in music technology and production, who in his times as an active musician toured with Helloween. Another one was gathered with Karl Spracklen (45 years), an expert on Northernness and Englishness, and a metal music scholar. Colin Büttner (40 years) contributed his experience as a German metal journalist, having interviewed Gamma Ray, Blind Guardian, Helloween, Michael Kiske and Dave Mustaine as head of www.metal.de's heavy, thrash and power metal resort, and having played in the power metal band Fairytale since 2000. Carl Delius (39 years) was interviewed as a die-hard power metal fan and leader of the German power metal band Torian, founded in 2002, who toured with DragonForce and Overkill.

\section{Definition and stylistic features of power metal}

Stylistically, power metal is difficult to define, not least due to the considerable overlap with related genres like heavy, true, speed and thrash metal. The AllMusic (n.d.) portal defines power metal as "everything from NWOBHM [New Wave of British Heavy Metal] bands to hardcoretinged thrashers like Pantera" that contrasts with the harshness and lack of melody common in death and black metal, further highlighting a "tight sense of groove" by "early- 90 s Teutonic outfits like Accept" and the classicist style with pseudo-operatic vocals of NWOBHM. Christe (2004: 95) complies with this definition, describing the music as a doubling of speed and crunch of classic heavy metal. In agreement, Sharpe-Young (2003: i) regards power metal as "Heavy Metal taken to the absolute, surgically precise, limit". The Metal Crypt (2004) stress a melodic rather than rhythmic style of guitar playing, high-pitched melodic vocals and double kick drum as being mandatory for the genre. They further differentiate between German ('Teutonic', heavier, less keyboard-driven), Italian (more melodic, classicistic, high-speed) and Swedish (mixture of German and Italian styles) power metal, claiming it to be a European genre basically. Metal Hammer (n.d.) describe power metal as a global genre with a considerable scene in the USA (more aggressive, less melodic, focused on guitar riffing, lower and less clear vocals), yet with greater popularity in Europe in the European forms.

The expert interviews complied with the definitions in literature but added further stylistic details. Spracklen defined power metal as "really technical, fast heavy metal" and Bauerfeind argued that a certain tempo range was expected in the genre, albeit not giving any concrete BPM numbers. Similarly, the technical virtuosity related to this required speed was emphasised by criteria given such as "virtuosic, fiddly solos" (Spracklen), "high-pitched vocals, very wide intervals and vocal acrobatics" (Mynett), "four or five octaves vocal ranges" (Delius), "tight performances" (Mynett) and "rhythmic and melodic precision" (Bauerfeind). This virtuosity, according to Mynett, resulted in a very controlled feel without any room for improvisation and the absence of 'groove'.

"The main differences to other genres of metal is very much about an absence of groove or swing or expressive kind of like rhythmic swing. In the same way that black metal has absolutely removed the blues influence from metal music, I think power metal has very much removed the groove or 
swing [...] that other genres of metal have got. It is very much about very straight metronomic drum performances."

The importance of vocal and guitar melodies was also highlighted, although this varied between the different substyles of the genre. These melodies, Bauerfeind stated, mostly were "simple, almost like in children's songs or in Schlager, just with a double kick drum". Production-wise, all respondents agreed that power metal required a good quality and that 'overproduction' was not an issue as it were with more extreme subgenres like death, doom or black metal. Mynett elucidated that

\begin{abstract}
"power metal is about power. It is about everything sounding full, sounding big, and in a different way than other genres. [...] It's a different type of heaviness. The heaviness is about energy, not about it being extreme. [...] It's not about being the fastest and the heaviest. It is about sounding powerful with a lot of energy and powerful vocal performances. [...] It's the production that fits the music. It's supposed to sound big [...] and that's what the production aesthetic is conveying."
\end{abstract}

As he continued, power metal had been the metal genre profiting the most from advancements in recording technology because it supported the full sound required for the power and 'cleanness', as Spracklen described it. On the other hand, Büttner, who has reviewed power metal releases for www.metal.de for ten years, criticised many productions sounding so similar that the bands were practically exchangeable. ${ }^{5}$ Another assumed reason for this uniform sound was the tradition-consciousness within the genre. Bauerfeind explained, since having emerged out of the NWOBHM, it was in the "definition of the genre that, if you want to be labelled 'real' power metal, you must avoid being too experimental and doing things you would like to do for musical reasons, because otherwise you would not fit to the genre anymore. [...] Power metal has this traditional origin which it mustn't lose". The other producers and musicians shared this view and confirmed the conservative approach regarding playing styles, formal structures, arrangement and orchestration. According to Lammert this was due to the rich instrumentation that needed conforming to classical music theory. Yet, differences between various forms of power metal were emphasised. Referring to symphonic or epic power metal, Lammert highlighted him having produced an orchestral bonus version of a Gloryhammer record (Space 1992: Rise of the Chaos Wizards, 2015) that even worked without any guitars and drums. In contrast, keyboards and other orchestral elements, according to Bauerfeind, were used in melodic power metal very sparsely. Furthermore, guitars and vocals were harmonised in fourths, fifths and octaves, something unimaginable in classical music theory, to have the openness and 'grandeur' of these perfect intervals. A harmonisation in thirds would make the sound 'sweet' and hamper with the intended power.

\title{
Origins and development of power metal
}

The genealogy of music genres is often disputed, and power metal is no exception as different views in academic and journalistic literature demonstrate. For Christe (2004: 92), power metal emerged with US-bands like Metallica who, influenced by Dio, Amored Saint and Manowar, "buttressed every aspect of their operations to double the impact of the riffs and the imagery", calling their music 'power metal'. In his understanding, this new form was just a transitional phase between heavy and thrash metal (Christe 2004: 136). In contrast, Sharpe-Young (2003: i) sees the rawness of thrash metal having been fertile ground for the emergent power metal since "a ready audience of metal fans lay waiting for something just as heavy but with sophistication". From this trend many profited and started successful careers as for instance the American bands Attack, Jag Panzer, Iced Earth, Savatage and Queensryche as well as European bands like Helloween, Gamma Ray, Blind Guardian, Running Wild and Grave Digger who were inspired by the NWOBHM, Iron Maiden and Judas Priest first and foremost. Sharpe-

\footnotetext{
5 To him, the producers were responsible for this standardised sound. This complies with Blind Guardian who stated in an interview that every production of Kalle Trapp, one of the main power metal producers of the 1980s and '90s, sounded practically the same (Fischer 1994).
} 
Young's historiography complies with Weinstein's (2011: 40) academic understanding that emphasises the role of German metal: "Power metal, which was begun in the mid-1980s by the German band Helloween, takes the NWOBHM sound and exaggerates its powerful tenor vocals and melodicism, while continuing the mystical/mythical/sci-fi themes". ${ }^{6}$ She further highlights Gamma Ray (Germany), Blind Guardian (Germany), HammerFall (Sweden), Iced Earth (USA), Jag Panzer (USA), Stratovarious (Finland) and Angra (Brazil) as internationally betterknown power metal groups (Weinstein 1991: 289).

For a deeper understanding of the genre's global popularity, the Metal Archives (2017) were analysed. On 1 October 2017, 6.173 power metal bands were registered between 1975 and 2017. The top ten countries USA (1.232), Germany (642), Italy (459), Spain (354), Brazil (328), Sweden (259), Japan (249), Argentina (212), Russia (193) and Canada (176) indicate that power metal was primarily located in Central Europe and North America except for Brazil, Argentina and Japan. Considering the emergence of the genre from around the early to mid-1980s, this geographical distribution matches metal music's first phase of globalisation across Western countries (Weinstein 2011: 44). The dominance of the US and UK also shows in the trajectory of power metal bands (Figure 1). Whilst the NWOBHM has undoubtedly spurred power metal, it still was the US and Germany having been the major players during the genre's first decade given that many other countries had not adopted the style before the late 1990s. ${ }^{7}$ However, it could be argued that British bands playing power metal kept the label NWOBHM, thereby distorting the statistics. ${ }^{8}$ Counting up the numbers of registered British bands, power metal (129) and NWOBHM (272), would promote the UK (401) to rank four in the table.

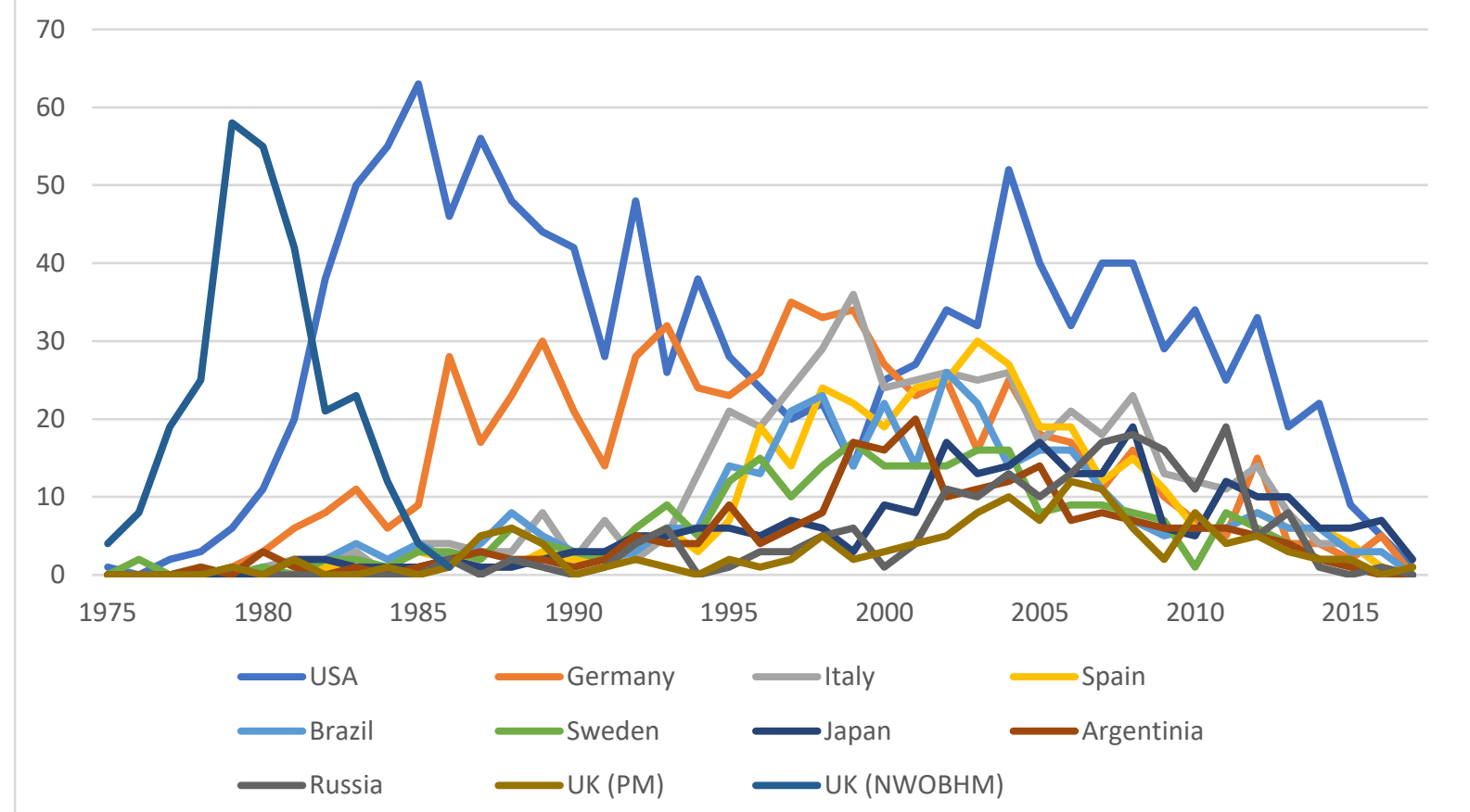

Figure 1. Trajectory of founded power metal bands of the top ten nations

\footnotetext{
${ }^{6}$ This assertion concurs with the Metal Crypt's (2004) entry on power metal that describes the Helloween albums Keeper of the Seven Keys parts 1 (1987) and 2 (1988) as the beginning of the genre. However, according to the Metal Hammer (n.d.), the term 'power metal' was first used in the context of the 'Power of Metal' tour by Gamma Ray, Rage, Conception and Helicon in 1993 and then became popular with the release of HammerFall's debut album Glory to the Brave (1997).

${ }^{7}$ Bands in less developed countries are likely underrepresented in the data due to restricted access to the Internet and lesser international renown. Yet this has no impact on the top countries in the table.

${ }^{8}$ Of the interview respondents, Delius claimed that "British power metal does not exist" and likewise Büttner stressed not to know more than a handful of British bands he would classify as power metal. Moreover, Wikipedia (2018) lists 54 US-American, 48 German and only 9 British power metal groups at the time of writing (April 2018).
} 
Although the Metal Archives may not provide accurate data, they still allow a rough approximation of the genre's popularity. Considering all registered entries on power metal, the number of founded bands per year rose with a maximum of 335 newly registered bands until 2004, then dropping with dwindling registrations, especially in the last three years: 2015 (61), 2016 (39) and 2017 (6).

\title{
Influences and inspirations
}

The spreading of metal music from the US and UK began in Central European countries before it expanded north to Scandinavia (Weinstein 1991: 118). Whilst there already was a vibrant hard rock scene in the 1970s with popular bands such as the Scorpions, Accept and Running Wild, the NWOBHM led to an outburst of metal in West Germany in the 1980s. Power metal bands like Helloween, Blind Guardian, Rage and Grave Digger as well as the thrashers Kreator, Sodom and Destruction were only the spearhead of the "early wave of heavy metal in Germany" (Elflein 2017: 116). The influence of the NWOBHM having triggered this strong movement was uncontested by the respondents. Bauerfeind remembered once having sat down with Michael Kiske (singer of Helloween and Avantasia) and let him play records that inspired him. Kiske's choice of music made Bauerfeind realise that Helloween had "sped up elements of Iron Maiden and added children's melodies". His own productions, however, were less inspired by the British sound. He admitted knowing Iron Maiden just by name until into the early 1990s, but eventually had to listen to them whilst preparing for a mastering session where this influence was desired. The same was true for Judas Priest as Bauerfeind recalled, "And then there was this situation when the singer came to me and requested a vocal sound like the one of Rob Halford. I only thought, sure, but 'Who the fuck is Rob Halford?' I didn't have the slightest idea". This ignorance was due to his intention to stay as 'self-contained' as possible to retain his individual style. ${ }^{9}$ Moreover, he admitted not to like the British production style, thinking it was 'woody', centred on mid-frequencies, featured the snare drum too much compared to the kick drum, and favoured mono compatible old-school miking techniques over the wide wall of sound common in America. This self-contained intention draws parallels with interview statements in journalistic literature. For example, Udo Dirkschneider of Accept once stated that taking note of NWOBHM very late had contributed to the band's unique style (Mader 1998a: 28). On the other hand, bands like Blind Guardian admittedly were influenced by NWOBHM and fellow German bands like Helloween but tried to find a balance between looking out for trends and finding their own style (Mader 1998b: 52). Mynett agreed to German bands influencing each other.

\begin{abstract}
"I think German power metal bands are clearly influenced by each other [...]. I think certain bands have been influenced by other bands, but then have become incredibly influential themselves. I think Helloween's Keeper of the Seven Keys part one [1987] and two [1988] was massive. It was a huge, huge influence on so many people. To me, the end of the ' 80 s, early ' 90 s was the real beginning of that German scene with Helloween. Obviously, Iron Maiden can be touched upon and I think Judas Priest can be touched upon these influences, and obviously both of those are British. But then you got a German scene and I think those German bands have definitely influenced each other. I think that's quite a powerful thing where you get a scene where different bands within the scene are influencing each other."
\end{abstract}

In Mynett's perception, bands from the US and UK were influenced by a wide range of genres even beyond metal whilst German musicians were little affected by other genres, mainly adapting ideas from fellow German metal bands. Büttner shared this view further stating that newer generations of German power metal bands were inspired by German bands like Gamma Ray or

\footnotetext{
${ }^{9}$ Bauerfeind also confessed not even having been fond of metal music. He started producing metal bands because very few jobs were available in commercial popular music, but whilst there was a lack of people producing metal at that time, he took the opportunity.
} 
Edguy at least as much as they were by the initial NWOBHM heroes. Bauerfeind and Mynett in this context highlighted the role of the Scorpions, especially their guitar playing and the deep, powerful snare drum sound that became characteristic for German power metal; an influence Bauerfeind experienced first-hand whilst working with acts like Blind Guardian and Axel Rudi Pell. Accept was another band whose importance was stressed for their straightforward style that influenced for instance Grave Digger. According to Mader (1998a: 29; translation), the "explosion of the German heavy metal scene, in retrospect, can be traced back to the success of Accept", especially of the album Breaker (1981).

\section{International impression and global success}

Accept and the Scorpions were Germany's most successful metal exports in the 1980s. With their origin obviously being German, most strikingly in the vocal styles of their singers (Henderson 1989: 14), it is interesting to explore to what degree the early power metal bands aimed at international success. Whilst performed Germanness can be utilised strategically as has been claimed about Rammstein (Kahnke 2013) and Kraftwerk (Littlejohn 2009), metal back then was sung in English, which likely was favourable to an international impression.

One band aiming at international success was Grave Digger. Their third album Wargames (1986) was an attempt to compete with bands in the league of Bon Jovi and Europe, yet it failed. Therefore, the band changed their style and renamed themselves 'Digger'. As singer Chris Boltendahl explained in the Rock Hard magazine (quoted in Hartmann 1998: 99; translation), it was the attempt of "pure commercial sell-out. We wanted to make loads of money. That's why we have changed our name and made the album Stronger than ever [1987] utterly commercial. The record initially was intended to reach the US market, but it has never been released there". Other bands, according to journalists of the book Heavy Metal made in Germany (Mader, Jeske \& Hofmann 1998), were far less driven by desire of success. Running Wild, for example, wanted to be distributed worldwide but objected being signed by a major label (Hartmann \& Mader 1998: 147f), and Kai Hansen allegedly left Helloween because he felt the increasing success and professionality interfered with the band's original intention of making music together as friends (Eichner 1998: 93). Bauerfeind confirmed this down-to-earth attitude of many of the bands that often conflicted with the interests of their record labels.

\footnotetext{
"Of course, the record labels were always interested in creating an internationally successful artist like the Scorpions, the Scorpions 2.0 so to say. But this definitely wasn't the intention of the bands. With bands like Kreator, I didn't even know they were a German band at the beginning. They immediately had an international touch due to their success, and they never appeared as a German band selling out their Germanness. The German origin was more apparent with Blind Guardian or Helloween. They just appeared this way even if they didn't intend to advertise their Germanness. Rather I would claim these bands were not interested in appearing international at all. Being authentic was far more important to them. The authenticity of bands like Blind Guardian, Gamma Ray, Helloween was much higher than that of bands like Thunderhead and others who always tried to succeed on the American Market. With Excelsis it was the same. When you start having an eye on international markets, it becomes difficult."
}

This international orientation was most visible with bands from Hanover as for instance Thunderhead, Victory and Sargant Fury who, according to Bauerfeind, tried to follow in the footsteps of the Scorpions.

"Ted Bullet, who sang for Thunderhead, was US-American. They have employed him for the audition with Victory. And then Charlie Huhn was replaced by Fernando Garcia, who soon after went to England to join Foghat. All this happened in an attempt to achieve an international touch. Many bands have tried to be successful internationally. [...] The Scorpions did succeed but a band like Victory more or less failed with the attempt to 'sell Coca Cola to America'. This, of course, is very difficult. [...] Even though bands like Thunderhead with singer Ted [Bullet] have made fantastic records, they never sold much abroad. [...] The same applies to Sargant Fury who with Mac [Andrew McDermott] had an English singer who later sang for Threshold." 
One reason for choosing a native English-speaking singer was their different style of writing lyrics. However, Bauerfeind explained, nobody was concerned about good lyrics in Germany, Europe, Asia or South America if the band sounded well. Only for bands who had phantasyoriented themes like Blind Guardian, the quality of the lyrics did matter. He further recalled that Angra (Brazil) tried to make better lyrics by having them reworked by other people. Yet “it never really sounded English, and it still was terrible because we didn't want to change the artist's intention completely. In the end, nobody in Japan and South America cared. [...] If they would have had success in the US had they written better lyrics, I doubt that very much". Similar statements can be found in literature, for example by the thrashers of Destruction, "We have never paid attention to the lyrics. The only sense we saw in lyrics was that you needed to sing something to the instruments. What it was, we didn't care about" (Mader 1998c: 86; translation).

There is reason to believe that this attitude has changed over time with increasing demand for correct English grammar and pronunciation. Even early bands like Helloween and Blind Guardian valuing authenticity eventually had their lyrics checked by native speakers. Furthermore, differentiating between British and American English was considered part of the artistic concept as Bauerfeind explained.

\footnotetext{
"Surely one tries not to sing total bollocks. You must imagine, it's a different thing to ask a British person about English than to ask an American. That's the same as with German dialects. You cannot start a sentence in Bavarian and then switch to Saxon. This works nowhere, neither in German nor in English. You must avoid mixing up British English with American English. For a band like Blind Guardian, British English seems more appropriate. But that they went for British English because of international compatibility, I don't think so."
}

The two interviewees playing in semi-professional bands, Büttner and Delius, complied with this described practice, confirming to pass on their lyrics to native speakers to proofread. Büttner explained,

"I find it quite important for the overall impression to have the lyrics checked when you see what bloomers bands like Blind Guardian and Sodom have had in the past. Back then, it was alright as it was funny and new and contributed to the chaos of Sodom. But not nowadays in times when everybody checks lyrics online or knows one or two English native speakers."

The accent too, as Bauerfeind indicated, was considered by these bands. Despite believing that British English sounded clearer, Delius reflected that his band decided to sing in American English because their style was influenced mostly by American bands, but also because the American culture was more present in Germany through music, television and films. Furthermore, singing in German had never been an option for both Büttner and Delius's bands. Whilst German lyrics would be appropriate for thrash metal due to its closeness to punk, power metal had to be sung in English, Delius explained, thereby complying with Klaus Meine of the Scorpions who in an interview elucidated that "German was inadequate to express metal feelings and themes" (Weinstein 2011: 45). The increased attention being paid to language was confirmed from a British perspective by Mynett, who recalled a French band choosing him because they wanted to have a native English-speaking producer that could correct lyrics and help with pronunciation. However, since power metal from Germany had become so characteristic on the global metal scene, international bands like Gloryhammer even adapted an artificial German accent, as producer Lammert elucidated, to be associated with the German sound.

Singing in English was hugely important for the international success not only of German metal bands but also of German record labels as Bemm, the main producer for the aspiring Century Media label, recalled. In the late 1980s and early '90s, small independent labels spread all over Germany. Unlike the major labels, they immediately focused on markets outside of Germany, Austria and Switzerland and strategically specialised in metal genres.

"These independents were clever and said, 'Let's see whether we can sell throughout Europe, or maybe even in England or America'. And they were successful right away. Having a worldwide 
distribution resulted in much better turnovers, also with German bands. Releasing internationally was the first step to a clear advantage over the majors. The independents were much more flexible because they didn't have such a huge apparatus. Robert [Kampf; founder of Century Media in Dortmund 1988] used to have his office in his bedroom. Now Century Media worldwide is more renowned than a major company [...], the same is true for Nuclear Blast [in Donzdorf]. [...] Everything happened very quickly. [...] Robert came to me with a cassette and asked me to listen and see whether it had any potential. [...] It worked exceptionally well, partly because the market was so manageable. This changed after a while and these 'independents' weren't so independent anymore, which became a problem for the bands who suddenly had to start signing dodgy contracts. [...] There nevertheless was a gigantic development in the Ruhr Area with Century Media and Gun Records enabling bands to make 'their step'. That fertile ground was most appreciated by the bands."

Just as Bauerfeind recalled being true for Helloween and Blind Guardian, Bemm stressed that many bands were not aiming at international success. Neither did they consider themselves being too good to play on school graduation parties, which the labels had made them do. Yet, the record labels' clever international distribution strategy eventually paid off, making them (Century Media, Steamhammer, Noise, Nuclear Blast, GUN) global players on the metal market and many of their German bands with them. As Bemm uttered, "It was like the Neue Deutsche Welle in the '80s. Come to Hagen [a medium sized city in the Ruhr Area], become a rock star".

\section{Establishment of a 'Teutonic' sound? The role of regional scenes and recording studios}

Metal in West Germany in the 1980s and early '90s was evenly spread between urban and rural areas (Elflein 2017: 119ff), yet certain cities stood out in terms of renowned bands and recording studios. Hanover was home to bands such as the Scorpions, Thunderhead, Victory and Sargant Fury plus studios like Horus (Gamma Ray, Grave Digger, Helloween, Kreator, Rage, Running Wild, Sodom, Steeler), Area 51 (Helloween, Thunderhead, Victory, Gamma Ray, Sargant Fury) and Gate Studios (Edguy, Avantasia, Heavens Gate). Further north in Hamburg were Running Wild, Helloween, Gamma Ray and Masterplan and main studios like the Château du Pape (Helloween, Gamma Ray, Rammstein, Victory, Thunderhead), Soundhouse Studio (Running Wild, Helloween, Pink Cream 69) and Hansen Studios (Brainstorm, Gamma Ray, Avantasia, Sieges Even, Stormwarrior). The south had famous studios like Musiclands (Led Zeppelin, Queen, Deep Purple, Iron Maiden). In West Berlin (Tempelhof), Harris Johns produced in his MusicLab (Sodom, Kreator, Helloween, Grave Digger, Angel Dust, Tankard, Exhumer). Yet much of the early German metal came from North Rhine Westphalia ${ }^{10}$, where it was produced by Dieter Dierks in his Dierks Studios near Cologne (Scorpions, Accept, U.D.O., Tangerine Dream, Can), Kalle Trapp in his Karo Music Studios in Münster and Brackel (Blind Guardian, Grave Digger, Gamma Ray, Iron Savior, Freedom Call, Destruction, Angel Dust, Sieges Even), Ulli Pösselt in the RA.SH Studios in Gelsenkirchen (Rage, Thunderhead, Axel Rudi Pell, Sodom, Tom Angelripper) and Siggi Bemm in the Woodhouse Studio in Dortmund and in Hagen (Kreator, Sodom, Morgoth, Samael, Angel Dust). ${ }^{11}$

This concentration of recording studios complies with Elflein's (2017: 116) analysis of bands according to which the locus of rock and metal swapped from Hanover to Hamburg and North Rhine Westphalia, particularly the Ruhr Area, which he describes as the "German equivalent to the Black country in the UK in heavy metal history". In the formative years, 103 out of the 312 bands in Elflein's sample were from North Rhine Westphalia, far ahead of Baden Wuerttemberg (42) and Lower Saxony (31). With 43 bands coming from the Ruhr Area in North Rhine Westphalia, this region - the largest industrial centre in Europe with 5.5 million

\footnotetext{
${ }^{10}$ Bauerfeind has never been a producer in the traditional sense, not having a studio of his own. Since a few years, however, he is based in Blind Guardian's Twilight Hall studio in Grefrath, North Rhine Westphalia.

${ }^{11}$ It is worth pointing out that famous bands from abroad were also recorded and produced in these studios; Karo Music Studios: Saxon, Molly Hatchet, Uriah Heep, Motörhead; Château Du Pape: Viper, Depeche Mode; Dierks Studios: Dokken, Twisted Sister; Hansen Studios: Angra; Gate Studios: Rhapsody of Fire, Kamelot, Epica; MusicLab: Krisiun, Celtic Frost, Voivod, Coroner, Moonstruck, Saint Vitus, Immolation.
} 
people in an area of 4,400 square kilometres (Hospers 2004: 148) - is considered the metal hotspot of the country (Schmenk \& Krumm 2010: Schmenk \& Schiffmann 2017). According to Krumm (2010: 358-359), this accumulation of metal bands was not the result of a deprived area as commonly portrayed by the German media but rather the consequence of a good infrastructure. According to Negus (1992: 29-30), "genre cultures [arise] from the complex intersection and interplay between commercial organizational structures and promotional labels; the activities of fans, listeners and audiences; networks of musicians; and historical legacies that come to us within broader social formations". With the Westfalenhalle Dortmund, Grugahalle Essen and the near Philipshalle Düsseldorf, the big rock and metal bands of the 1980s performed in the Ruhr Area on their German tours, and it was in Dortmund the first Monsters of Rock festival in Germany (1983) took place (Krumm 2010: 360). ${ }^{12}$ When this flourishing industrial region began to decline, the pits became cultural institutions, e.g. the Zeche Carl in EssenAltenessen and Zeche Prinz Regent in Bochum-Weitmar, providing meeting spots for metal fans, not only concert venues and locations for scene events such as transregional metal markets but also rehearsal rooms for many emerging metal bands. Other advantages were the radio reception of the British armed forces channel BFBS, broadcasting the weekly 'Heavy Metal Show' moderated by Tony Jasper (Schmenk \& Krumm 2010: 28-29), the closeness to the welldeveloped Dutch metal scene with the Aardschock magazine, Roadrunner records, a vibrant tape trading scene (Krumm 2010: 359-360), and the Dynamo Open Air (Schmenk \& Krumm 2010: 28). Moreover, most of the renowned metal magazines were located in the Ruhr Area; the two biggest ones Rock Hard (since 1983) and Metal Hammer (since 1984), a German version of the Dutch Aardschock, the Desaster and the 'Metal-Maniacs-Germany' fan club with an eponymous magazine. Many of the influential metal labels (Century Media, GUN Records, Earthshaker Records) and management firms (Kopec Musikverlag, Drakkar) also established there. This creative environment helped thrash metal (Kreator, Sodom) and traditional heavy metal (Accept, Grave Digger, Warlock, Rage) flourish and leave a mark on the global metal scene of the 1980s.

Hamburg, by comparison, was renowned for speed metal - a generic term used for both power metal and thrash metal for a lack of distinction - with bands such as Running Wild, Iron Angel, Helloween, Gamma Ray and Iron Savior. Similar to the Ruhr Area, international bands regularly played at big venues such as the Markthalle, and the NDR broadcasted a heavy metal special on radio once a month (Helbic 1987). Hannover was characteristic for its Scorpionsinspired hard rock sound with bands like Victory, Sargant Fury and Thunderhead. In southern Germany bands like Bonfire, Sinner, Chroming Rose, Pink Cream 69 and Primal Fear played melodic hard rock, hairspray metal and power metal, often influenced by American rock music played in the clubs of the US military (Mader, Otger \& Hofmann 1998: 18).

Initially, many bands had members from their city or region, but soon the scene professionalised and musicians of more successful bands frequently changed groups, which made a consistent line-up a rarity. Guest appearances on other bands' records were common too. Notwithstanding this mixture of musicians, the use of the same set of studio resources and the small group of aforementioned producers, there still developed a nationally rather coherent sound despite regional differences.

According to Bauerfeind, the recording studios with their characteristic acoustics and equipment were hugely important for the metal sound of that time.

"I'm convinced these handful of producers only worked in certain studios. Everything was based around these few studios, and they were completely different in their idiosyncrasies. For example, the RA.SH Studios [in Gelsenkirchen] were located in an old WWII bunker. It was pretty much contorted and had a very unique sound. It also had a distinct mixing console, a Neve, which created

\footnotetext{
${ }^{12}$ Whilst the Monsters of Rock festival (1983) was a significant moment in the history of metal in the Ruhr Area, insiders regard the Kiss concert in Dortmund (1980) with support band Iron Maiden as the starting point of the regional metal scene (Schmenk \& Krumm 2010: 29).
} 
a particular sound. At Kai's [Hansen] studio, also in a WWII bunker, everything was much more 'wooden' because it was designed that way and had different technology. Karo Music Studios [in Brackel and Münster; Figure 2] had a very unique sound too, a very warm and 'wooden' sound, which shaped the sound of the guys [Blind Guardian]. This was a very different sound to the Imaginations [From The Other Side, 1995] that they recorded up north at the Sweet Silence Studios [in Copenhagen]. [...] At the Sweet Silence, the drums were recorded in a room with brown-red clinker bricks. But the real cool thing was the storage room behind it. If you opened the big double doors, there was this storage room of 300 to 400 square metres. If you placed a microphone into this room whoa, this natural reverb, this clanking. [...] This was similar at the RA.SH Studios. It had a few reverb chambers. And it had stairways, everything built of concrete. We used all these room acoustics to create sounds. These were very, very unique sounds. And this rawness, just like in the room over here [Figure 3], this is exactly what that kind of music needs."

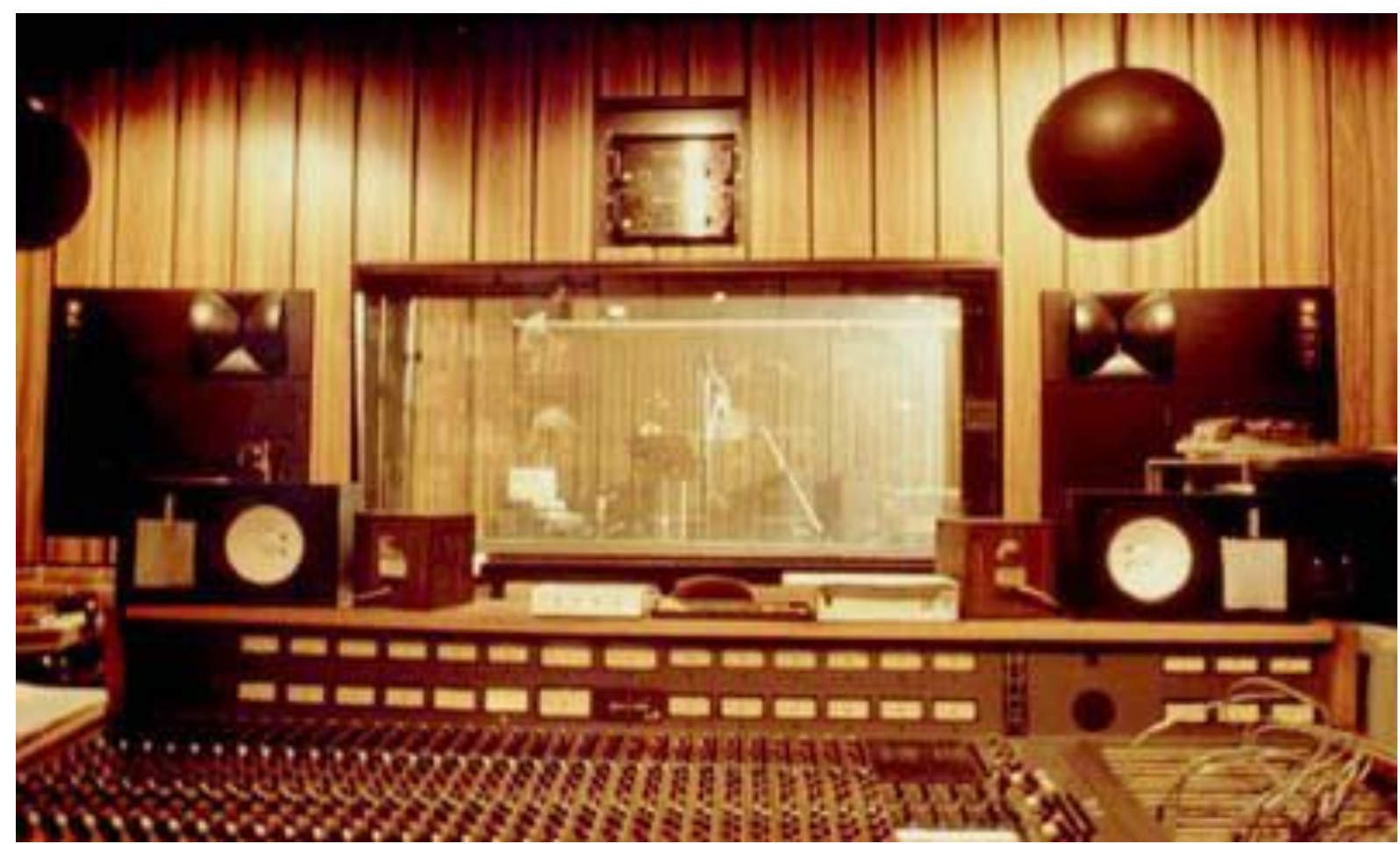

Figure 2. View into Karo Music Studio's live room from the control room ${ }^{13}$

\footnotetext{
${ }^{13}$ https://www.discogs.com/label/301486-Karo-Musikstudio. Accessed 16 April 2018.
} 


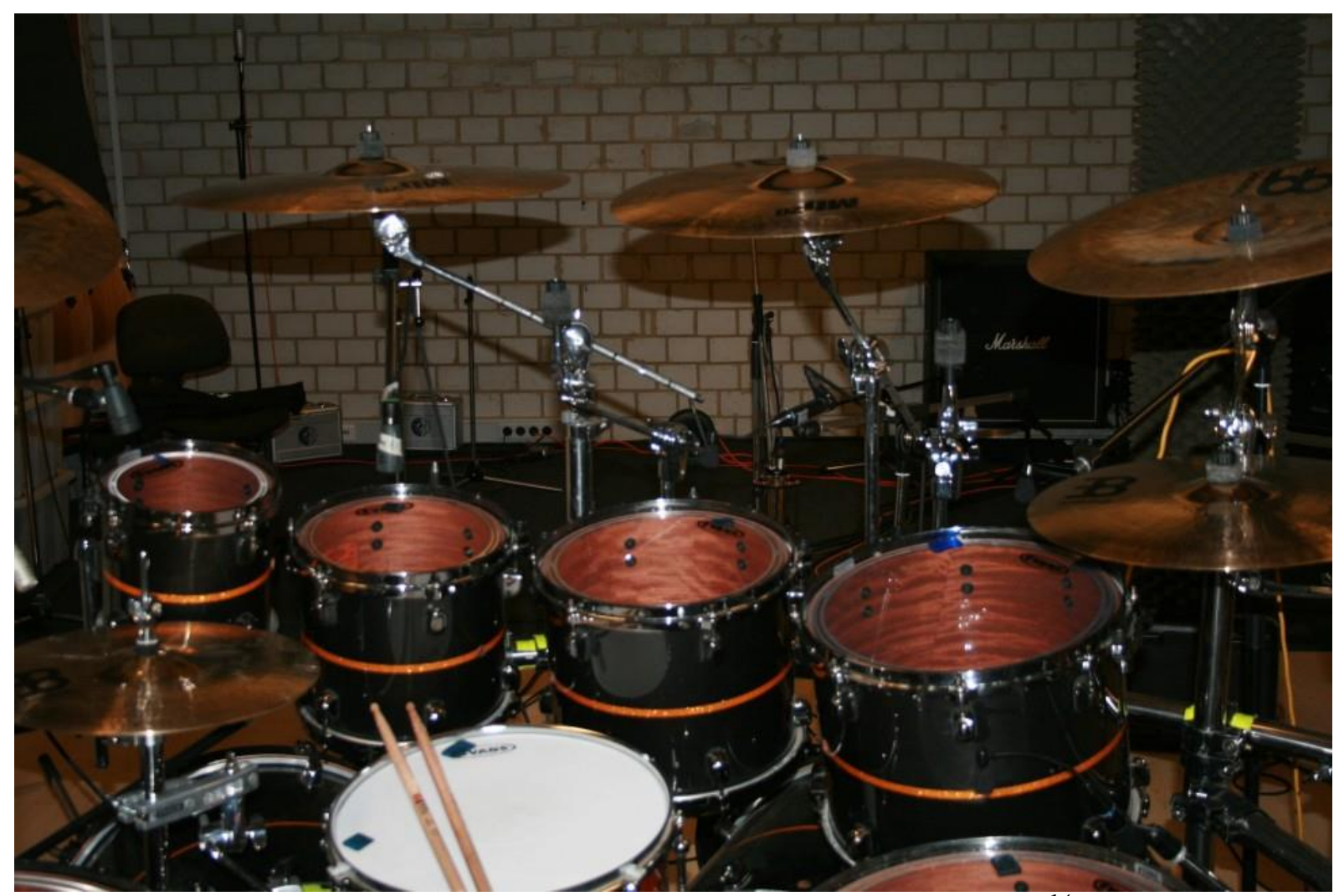

Figure 3. Drum recording room of Blind Guardian's Twilight Hall Studio ${ }^{14}$

These varying acoustic characteristics of the recording rooms were essential, also for Bemm: "My shack was legendary for its drum sound. Because I'm nuts, I had fitted out my recording room with glazed tiles on the walls. Sane people wouldn't put a drum set in there. But with this you create a drum sound that sounds like a real drum set. Very powerful and ambient". Another important studio for power metal productions at that time was the Wisseloord in the Netherlands. Bauerfeind recalled:

\begin{abstract}
"The Wisseloord was very controlled. It had compressing roofs that created acoustic pressure. Those were the attributes we were looking for to create these particular drum sounds. To create canon [kick drum] and gunshot [snare drum] you need the right acoustics. Nowadays, you don't find something like that anymore. Nowadays they celebrate broadcasting studios. If I had told people in the '90s I wanted to record drums in the broadcasting studios of the WDR [West German Broadcast Corporation], they would have punched me in the face. Nobody would ever have come up with such an idea. But today, this is how it is done. And to be honest, that is why it sounds so boring today. [...] In the early years, when all the producers and engineers went to the same few studios with their particular acoustics and equipment, this contributed to the typical 'Teutonic' metal sound."
\end{abstract}

Bemm further emphasised the main engineers with their individual sonic signatures were important for the unique studio sounds. Both Bemm and Bauerfeind agreed that few other studios played a role back then because there were either those big ones or the small home studios not suited for professional productions. With increasing success, bands like Blind Guardian, Gamma Ray, Running Wild and Helloween refused to spend their money on expensive studios and built their own production facilities. Greater affordability of studio resources and changes in the music industry gradually led to a pluralisation and thus to a decline of the unique studio characteristics that according to Bauerfeind were so important for the early German metal sound.

"These sound characteristics were much more important in the past. Today, the kids don't have money to go to such studios. If I see pictures of their drum recordings I can tell how it sounds, and

\footnotetext{
${ }^{14}$ http://www.blind-guardian.com/popups/images/xmas2009/IMG_4115-resize.jpg. Accessed 15 April 2018.
} 
the only reason it sounds good is because everybody is using the same library samples. In the past, every studio really differed from each other and we went to a particular studio because of its unique sound. This absolutely doesn't happen anymore today.“

That has become usual practice as the other producers confirmed. Mynett added that most bands nowadays recorded themselves in their own studios or rehearsal rooms and then sent the recordings over the Internet to have them mixed and mastered. As the rooms were often not fitted for great sounding recordings, their acoustics were captured as little as possible by using close miking techniques. Lammert confirmed the decreasing relevance of studio rooms, explaining most of his clients do not even know his studio's name but would employ him for his reputation as a producer. What is more, he argued that most German power metal bands were produced abroad today.

"There is not much German in the productions anymore. All the German producers, Bauerfeind or Wagner, who now is in America, have shaped this sound as Germans producing the German bands. But in the last ten years, that was hardly the case. In the last ten years, English or Scandinavian producers have been doing it."

Although there certainly are German bands using their access to global production resources, for example the German metal pioneers Accept having been produced by British producer Andy Sneap, Lammert's notion is likely a matter of misconception as liner notes of recent releases indicate. Bands still work with German producers as for instance Blind Guardian (Bauerfeind), Rage (Bauerfeind), Helloween (Bauerfeind), Axel Rudi Pell (Bauerfeind), Van Canto (Bauerfeind), Gamma Ray (Eike Freese), Avantasia (Sascha Paeth), Edguy (Sascha Paeth), Axxis (Bernhard Weiss), Freedom Call (Chris Bay) and Mob Rules (Markus Teske). Some even produce themselves (Rage, Michael Kiske, Running Wild, Grave Digger, Primal Fear, Iron Savior, Wizard, Sacred Steel, Orden Ogan, Pink Cream 69). Moreover, bands like Helloween were already being produced internationally in their early years (e.g. by the Danish Tommy Hansen and the English Chris Tsangarides). The globalisation of recording practices and resources yet seems to have contributed to the blurring of distinct metal styles and audible geographical origins. Furthermore, landmark studios of early German metal such as RA.SH (Gelsenkirchen) and Karo (Münster) closed down and their operators (Trapp, Pösselt) stopped producing music.

\section{Musical and performative characteristics of 'Teutonic' metal}

Apart from the influence of studio acoustics, equipment and engineers on early German power metal, all interviewees but Bemm believed there was a German or 'Teutonic' sound based on musical and performative characteristics. He was not convinced because for him the sound only depended on the musicians, engineers and producers involved. But even the proponents did not agree on the boundaries and associations of 'Teutonism'. Whilst both British experts limited the label to Germany, none of the German participants saw the geographical and cultural boundaries that exclusive, complying with the Metal Hammer definition (Schurer 2009). Bauerfeind even argued that 'Teutonic' culture was associated with Central Europe, based on their common musical heritage of 'classical' composers like Bach, Mozart and Beethoven plus traditional marching music. This musical heritage he contrasted to Slavic cultures (e.g. Dvorák) and to the American continent with its African-influenced swing rhythms. Rating the Central European in comparison to the American divide, Bauerfeind believed the rhythmic feel to be the key difference.

"Why does an American band swing whereas a European doesn't? Because in America you count
on two and four and in Germany it is one, two, three, four. This divides the two cultures, and this
also shows in the drum performances. I know very few American drummers who can play Teutonic
metal. $[\ldots]$ One of the few is Mikkey Dee ${ }^{15}[\ldots]$. He sits down and asks if I want it to be played in
a European or an American way. The American drummers are always laid-back, have their snare

${ }^{15}$ Dee is Swedish but played in bands from all over the world (Motörhead, King Diamond, Dokken, Helloween, Thin Lizzy, Scorpions). 
drums slightly behind. This doesn't work at all in 'Teutonic' metal because the attack the ear is picking up is so important. I don't want it to be masked by the kick drum. That's why the snare in 'Teutonic' metal always belongs slightly ahead of the snare. That is an absurdity to American drummers because they have been trained to play laid-back. [...] What they can do really well is a $6 / 8$. Why? Because it is a swing feel. If you can get a German metal drummer to play a triplet, then you are lucky. But there are very few American bands that can sound 'Teutonic'. For me, one of them is Manowar, they come very close."

The alignment of all drum instruments as well as the other instruments to the drums was crucial and had to be perfect to achieve the precise 'Teutonic' sound. Although questioning the notion of a 'Teutonic' sound, Bemm confirmed Bauerfeind's claim of rhythmic differences between performances of American and German musicians.

\begin{abstract}
"Many American productions are recorded live and are not quantised. This is a way of dealing with music that is completely different to what is done in Germany. Here everything has to be exact. Everything must fit. Micrometre calliper. 'Hmm... the 16" tom could be a bit earlier...'. The English are more like the Americans. Much more open-minded and relaxed. The Irish are relaxed too. But the Germans are exact."
\end{abstract}

Mynett also agreed to this, "German power metal bands sound absolutely German. [...] I definitely think there is a German or 'Teutonic' metal sound. I think that comes back to very precise structures, it is reflective of the German saying 'alles in Ordnung', very much about metronomic performance. It's very, very tight. There is a lot synchronisation going on". This metronomic feel meant a quality attribute to Bauerfeind, taking it a compliment when a rock producer once criticised the drums on his records sounding as precise as a drum computer. This aesthetics precisely matches the cultural and musical stereotypes portrayed most famously by Kraftwerk (Barr 1998; Adelt 2012) and complies with foreign expectations (Everley 2001) on how German music ought to sound. Bauerfeind further explained the Brazilian power metal band Angra having hired him, along with the German session drummers Alex Holzwarth (Sieges Even, Avantasia, Rhapsody of Fire) and Thomas Nack (Gamma Ray, Iron Savior), to get rid of their South American feel in favour of 'Teutonic' precision. But he also recalled conflicts due to this 'Teutonic' mentality, for example when working with the British band Venom who did not share his preference for quantised sounding drum performances.

'True' Teutonic bands, Bauerfeind claimed, needed both rhythmic precision and all drum hits sounding identically so that differences in loudness between the two feet playing double kick drum were eliminated. This preciseness also concerned the guitar performances where downstrokes were preferred to reduce the irregular sounds and volumes of alternate picking. To increase precision and impact of the guitar sound, Bauerfeind revealed to have experimented with a technique that producer Robert John 'Mutt' Lange initially recorded on Def Leppard's Hysteria (1987), whereby guitar strings are recorded subsequently to eliminate the time differences when hitting the strings with a regular strum. However, this technique was not satisfying inasmuch as it did not maximise impact but resulted in a soft sound similar to a synthesiser, so Bauerfeind only used it on a bonus version of Helloween's ballad "As Long as I Fall" (2007) released in Japan. In another case, he blended in several layers of marching boot sounds to support the 'Teutonic' feeling on the Helloween track "Smile in the Sun" (2010), copying a strategy of Rammstein (e.g. "Links 23 4", 2001). ${ }^{16}$ There were other characteristics as for instance drum tunings and sounds (very loud and full-bodied kick drum), specific guitar amplifiers (Engl made in Germany) and different sounding guitar distortion (narrower distortion due to the $60 \mathrm{~Hz}$ mains frequency in America and Asia compared to the $50 \mathrm{~Hz}$ in Europe) also contributing to the 'Teutonic' sound, but for Bauerfeind these just were the finish on the characteristic rhythmic feel.

\footnotetext{
${ }^{16}$ Marching boot sounds with emphasis on the beats one and three have also been used by US-American bands like Kamelot ("March of Mephisto", 2005), but they play European style power metal with a Norwegian singer. However, such marching boot samples have already been used on Accept's famous "Balls to the Wall" in 1983 long before Rammstein.
} 


\section{Conclusion}

Is there such a thing as a 'Teutonic' (power) metal sound? In a recent interview (Texan) Dennis Ward, founder of south German band Pink Cream 69 and Germany-based metal music producer, was asked by Rock Hard if there was a German metal sound.

\footnotetext{
"Oh, indeed, there definitely is one. Just a few days ago I got a request, one of the kind I often receive. The band was from Italy and they wanted me to make them sound like 'all the great German metal bands'. This probably is the best evidence. But I cannot explain what exactly makes up this sound given Accept sounding totally different to Helloween. There must be some common element. Maybe this kind of music from Germany is produced with more reverb, roomier and not so dry and 'in your face' as much of the music coming from the US." (Schiffmann 2018: 75; translation)
}

This statement complies with the results of the current investigation, highlighting the acoustics of German recording studios and possibly digital emulations in modern production practice. It also demonstrates how challenging it is to pin down the characteristics of a German or 'Teutonic' metal sound. Whether it is still distinct today or rather an aesthetic ideal reflecting the glory of early German metal bands remains open in Ward's response. Yet, according to the findings in this study, it is most likely that a characteristic German power metal sound existed in the 1980s and '90s. The genre developed just after the emergence of metal in the US and UK, and Germany was amongst the few countries to burst out countless successful power metal bands before the genre spread to other parts of the world years later. What is more, there were no standards when the genre emerged, and production resources were limited and individual. It can be assumed that it exactly was this restricted infrastructure - the unique characteristics of a few recording studios and instruments from Germany together with the small circle of professional musicians, engineers and producers - that has shaped the classic German power metal, a sound admired and copied by bands of the calibre of the Swedish HammerFall (Schäfer 1998), the most 'Teutonic' metal band outside of Germany according to Bauerfeind. ${ }^{17}$ However, these national characteristics gradually diminished with standardisation of production resources (e.g. neutral-sounding DAWs compared to individual analogue consoles; artificial reverberation instead of natural room ambience) and new techniques (e.g. drum sound replacement and quantisation) besides other consequences of globalisation such as internationally operating record labels, American culture in public media and increased English language skills. ${ }^{18}$

The 'Teutonic' label requires greater attention in future research given the connotations that vary in geography and content as the interviews demonstrated. Elflein (2017: 122) subsumed both thrash and power metal bands under this label. However, not all respondents did associate thrash metal with the 'Teutonic' label, which is common on the Internet in the context of thrash. Furthermore, most of the German interviewees insisted on differences between 'Teutonic power metal' and 'German power metal'. Whilst 'German power metal' stood in the tradition of Helloween, Blind Guardian and Rage featuring elaborate symphonic compositions and lyrics, twinguitar harmonies and melodicism, 'Teutonic power metal', defined by its simple, unrefined and rhythm-focused character and its strong influence from hard rock bands like AC/DC rather than the NWOBHM, was associated with the tradition of Accept and Grave Digger. Further research is needed to confirm whether or not there are two distinct styles of German power metal. Distinction of British (NWOBHM), American, Scandinavian ('Viking'), German ('Teutonic') and other geographically connoted metal sounds and cultures plus their eventual overlapping amongst each other could be explored too. Notwithstanding metal scenes frequently using these labels, naming the respective defining characteristics and differences proved difficult even for the interviewed experts.

\footnotetext{
${ }^{17}$ HammerFall deliberately chose German producers for most of their albums until starting to produce themselves; Michael Wagener for his work with Accept and Charlie Bauerfeind for his 'Teutonic' sound.

${ }^{18}$ This complies with Zagorski-Thomas' (2012) findings of distinct production sounds in the US and UK to have assimilated as early as in the 1970 s.
} 


\section{References}

Adelt, Ulrich (2012). Machines with a Heart. German Identity in the Music of Can and Kraftwerk. Popular Music and Society 35(3), pp. 359-374.

AllMusic (n.d.). Power Metal. Online: www.allmusic.com/style/power-metal-ma0000011913. Accessed 10.4.2018.

Anderson, Benedict (1983). Imagined Communities. London: Verso.

Barr, Tim (1998). Kraftwerk: From Düsseldorf to the Future (with Love). London: Ebury Press.

Bender, Hilmar (2011). Violent Evolution. Die Geschichte von Kreator [The history of Kreator]. Diedorf: Ubooks Verlag.

Brown, Andy R.; Spracklen, Karl; Kahn-Harris, Keith \& Scott, Niall W. R. (2016) (Eds.). Global Metal Music and Culture. Current Directions in Metal Music. London: Routledge.

Burns, Robert (2008). German Symbolism in Rock Music. National Signification in the Imagery and Songs of Rammstein. Popular Music 27(3), pp. 457-472.

Christe, Ian (2004). Sound of the Beast. The complete headbanging history of heavy metal. New York: Harper Collins.

Cohen, Anthony (1985). The Symbolic Construction of Community. London: Travistock.

Dallach, Christoph (2003). Die Maschinen spielen uns: Interview mit Ralf Hütter. Der Spiegel, 13 July 2003, pp. 154-155.

Dome, Malcolm (1987). Helloween. Key to the door. Kerrang! 156 (Special Issue), p. 16.

Duden (2018). Teutone. Online: https://www.duden.de/rechtschreibung/Teutone. Accessed 30.8.2018.

Eichner, Sandra (1998). Gamma Ray. In: Matthias Mader, Otger Jeske \& Arno Hofmann (Eds.). Heavy Metal - Made in Germany. Berlin: I.P. Verlag, pp. 93-97.

Elflein, Dietmar (2017). Restless and wild. Early West German heavy metal. In: Michael Ahlers \& Christoph Jacke (Eds.). Perspectives on German Popular Music. London: Routledge, pp. 116-122.

Everley, Dave (2001). Rammstein. Germanic Street Preachers. Kerrang! 847, pp. 44-45.

Fischer, Fabian. (1994). Blind Guardian. Die ganze Geschichte. Heavy oder was!?, 11, pp. 14-17.

Gehlke, David E. (2017). Damn the Machine. The Story of Noise Records. Pittsburgh: Deliberation Press.

Hartmann, Ralf (1998). Grave Digger. In: Matthias Mader, Otger Jeske \& Arno Hofmann (Eds.). Heavy Metal - Made in Germany. Berlin: I.P. Verlag, pp. 98-101.

Hartmann, Ralf \& Mader, Matthias (1998). Running Wild. In: Matthias Mader, Otger Jeske \& Arno Hofmann (Eds.). Heavy Metal - Made in Germany. Berlin: I.P. Verlag, pp. 143-150.

Heesch, Florian (2014). Nordisch - Germanisch - Deutsch? Zur Mythenrezeption im Heavy Metal. In: Dietrich Helms \& Thomas Phleps (Eds.). Typisch Deutsch: (Eigen-)Sichten auf populäre Musik in diesem unserem Land. Bielefeld: transcript, pp. 127-151.

Helbic, Mark (1987). Hamburg Intern. Iron Pages, 8, pp. 8-9.

Henderson, Paul (1989). Thunderhead. Donner und Blitzen! Kerrang! 1989/268, p. 14.

Herder, Johann Gottfried (1796). Iduna, oder der Apfel der Verjüngung. In: Heinrich Düntzer (Ed.). Johann Gottfried Herder. Gesammelte Abhandlungen, Aufsätze, Beurtheilungen und Vorreden aus der Weimarer Zeit. Berlin: Hempel. Online: http://gutenberg.spiegel.de/buch/gesammelte-abhandlungen-aufsatze-beurtheilungen-und-vorreden-aus-der-weimarer-zeit-6505/16. Accessed 1.9.2018.

Hospers, Gert-Jan (2004). Restructuring Europe's Rustbelt. The Case of the German Ruhrgebiet. Intereconomics, 39(3), pp. 147-156.

Kahn-Harris, Keith (2007). Extreme Metal: Music and Culture on the Edge. Oxford: Berg. 
Kahnke, Corinna (2013). Transnationale Teutonen. Rammstein Representing the Berlin Republic. Journal of Popular Music Studies 25(2), pp. 185-197.

Kerrang! (1986). Accept, Teutonic Titans. Kerrang! 113, p. 6.

Kerrang! 1996. Short review: Rammstein - Herzeleid. Kerrang! 592, p. 45.

Krumm, Christian (2011). "Auf einmal ist es explodiert". Die Entstehung der Metalszene im Ruhrgebiet. In: Rolf F. Nohr \& Herbert Schwab (Eds.). Metal Matters. Heavy Metal als Kultur und Welt. Münster: LIT, pp. 357-366.

Littlejohn, John T. (2009). Kraftwerk. Language, Lucre, and Loss of Identity. Popular Music and Society 32(5), pp. 635-653.

Mader, Matthias (1998a). Accept. In: Matthias Mader, Otger Jeske \& Arno Hofmann (Eds.). Heavy Metal - Made in Germany. Berlin: I.P. Verlag, pp. 28-32.

Mader, Matthias (1998b). Blind Guardian. In: Matthias Mader, Otger Jeske \& Arno Hofmann (Eds.). Heavy Metal - Made in Germany. Berlin: I.P. Verlag, pp. 50-56.

Mader, Matthias (1998c). Destruction. In: Matthias Mader, Otger Jeske \& Arno Hofmann (Eds.). Heavy Metal - Made in Germany. Berlin: I.P. Verlag, pp. 84-88.

Mader, Matthias; Jeske, Otger \& Hofmann, Arno (1998) (Eds.). Heavy Metal - Made in Germany. Berlin: I.P. Verlag.

Metal Archives (2017). Online: www.metal-archives.com. Accessed 1.10.2017.

Metal Crypt (2004). Brief Description of Metal Genres, as they are used as a reviewing and classification tool. Online: https://www.metalcrypt.com/genres.php. Accessed 10.4.2018.

Metal Hammer (n.d.). Power Metal. Online: www.metal-hammer.de/genres/power-metal. Accessed 10.4.2018.

Negus, Keith (1992). Producing Pop. Culture and Conflict in the Popular Music Industry. London: Routledge.

Okunew, Nikolai (2016). 'Satan demands total annihilation': Heavy metal in the German Democratic Republic. Metal Music Studies 2(2), pp. 199-214.

Reynolds, Dave (1989). Review: U.D.O. - Mean Machine. Kerrang! 227, p. 25.

Rüther, Tobias. "Florian Schneider. Die Stimme der Energie". Frankfurter Allgemeine Zeitung 7 January 2009. Online: http://www.faz.net/aktuell/feuilleton/pop/florian-schneider-diestimme-derenergie-1753904.html. Accessed 30.8.2018.

Schäfer, Wolfgang (1998). Hammerfall. A Tribute to German Heavy Metal. Rockhard 1998/10, pp. 20 22.

Schiffmann, Andreas (2018). Dennis Ward. Rock Hard, 2018/8, p. 74-75.

Schmenk, Holger; Krumm, Christian (2010). Kumpels in Kutten. Heavy Metal im Ruhrgebiet [Mates in cut-off jackets. Heavy metal in the Ruhr District]. Bottrop: Verlag Henselowsky Boschmann.

Schmenk, Holger; Schiffmann, Andreas (2017). Kumpels in Kutten 2. Heavy Metal im Ruhrgebiet [Mates in cut-off jackets. Heavy metal in the Ruhr District 2]. Bottrop: Verlag Nicole Schmenk.

Schöwe, Andreas (1992a). Running Wild. The Very First Years of Piracy. Metal Hammer, 1992/1, pp. 112-113.

Schöwe, Andreas (1992b). Grave Digger. Metal Hammer, 1992/4, p. 136.

Schöwe, Andreas (2002). New Wave of British Heavy Metal. Metal Hammer, 2002/12, pp. 40-43.

Schuhmacher, Michael (2014). Tankard. Life in Beermuda. Die etwas andere Biographie [The somewhat other biography]. Bottrop: Verlag Nicole Schmenk.

Schurer, Petra (2009). Teutonischer Tod. Metal Hammer, 2009/6 (Special Issue), p. 6.

Sharpe-Young, Garry (2003). A-Z of Power Metal. London: Cherry Red Books. 
Spracklen, Karl \& Henderson, Stephen (2013). "Oh! What a tangled web we weave”. Englishness, communicative leisure, identity work and the cultural web of the English folk morris dance scene. Leisure/Loisir 37(3), pp. 233-249.

Stappert, Andreas (2004). UDO. Die Rente kann warten. Rock Hard, 2004/6, p. 92.

Wallach, Jeremy; Berger, Harris M. \& Greene, Paul D. (2011). Affective overdrive, scene dynamics, and identity in the global metal scene. In: Jeremy Wallach, Harris M. Berger \& Paul D. Greene (Eds.): Metal rules the globe. Heavy metal around the world. Durham: Duke University Press, pp. 3-33.

Weinstein, Deena (1991/2000). Running with the Devil: Power, Gender and Madness in Heavy Metal Music. Boston: Da Capo Press.

Weinstein, Deena (2011). The globalization of Metal. In: Jeremy Wallach, Harris M. Berger \& Paul D. Greene (Eds.): Metal rules the globe. Heavy metal around the world. Durham: Duke University Press, pp. 34-59.

Wiederhorn, Jon; Turman, Katherine (2013). Louder than hell. The definitive oral history of metal. New York: Harper Collins.

Wikipedia (2018). List of power metal bands. Online: https://en.wikipedia.org/wiki/List_of_power_metal_bands. Accessed 1.9.2018.

Zaddach, Wolf-Georg (2016). Metal militia behind the Iron Curtain: Scene formation in 1980s East Germany. Metal Music Studies 2(3), pp. 357-376.

Zagorski-Thomas, Simon (2012). The US vs the UK Sound. Meaning in Music Production in the 1970s. In: Simon Frith \& Simon Zagorski-Thomas (Eds.): The art of record production. An introductory reader for a new academic field. Farnham: Ashgate, pp. 57-76. 